\title{
RP-HPLC Method Development and Validation for the Analysis of Pharmaceutical Drugs - Paracetamol
}

\author{
Dr. Bhaskarrav N. Makwana
}

Municipal Arts and Urban Science College, Mehsana

\begin{abstract}
A simple, selective, linear, precise and accurate RP-HPLC method was developed and validated for rapid assay of PARACETAMOL. Isocratic elution at a flow rate of $1.0 \mathrm{ml} / \mathrm{min}$ was employed on a symmetry C18 column at ambient temperature. The mobile phase consisted of Acetonitrile: 0.1M Acetic Acid 50:50 (v/v). The UV detection wavelength was at $210 \mathrm{~nm}$. Linearity was observed in concentration range of $100-140 \mathrm{mg} / \mathrm{ml}$. The retention time for Paracetamol was 3.0 min. The method was validated as per the ICH guidelines. The proposed method can be successfully applied for the estimation of Paracetamol.
\end{abstract}

Keywords: Paracetamol, Method Development, Validation, 210nm

\section{Introduction}

DRUGS: Paracetamol

Structure:

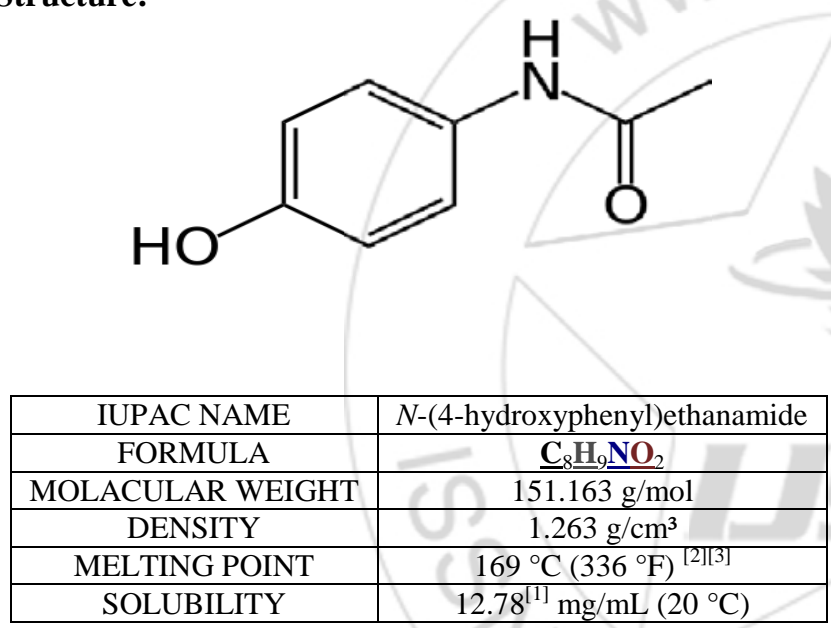

PHARMACOKINETIC DATA

\begin{tabular}{|c|c|}
\hline BIOAVAILABILITY & $\sim 100 \%$ (oral) \\
\hline PROTEIN BINDING & Low (31\%) \\
\hline METABOLISM & 90 tae $95 \%$ Hepatic \\
\hline HALF-LIFE & $1-4 \mathrm{~h}$ \\
\hline EXCRETION & Renal \\
\hline
\end{tabular}

Paracetamol, also known as acetaminophen or APAP, is a widely used over-the-counter pain medication and medication to reduce fever. ${ }^{[3][4]}$ It is commonly used to help with headaches, other minor aches and pains, and is a major ingredient in many cold medications. In combination with opioid analgesics, paracetamol is used in the management of more severe pain such as post-surgical and cancer pain. ${ }^{[5]}$ Though paracetamol is used to treat inflammatory pain, it is not classified as an NSAID because it exhibits only weak anti-inflammatory activity. While generally safe for use at recommended doses, even small overdoses can be fatal. Compared to other over-the-counter pain relievers, paracetamol is significantly more toxic in overdose but may be less toxic when used chronically at recommended doses. ${ }^{[6]}$ Paracetamol is classified as a mild analgesic.

\section{Experimental}

Chemicals and reagents

All HPLC SOLVENTS used like Acetonitrile, Acetic Acid which are of HPLC grade were purchased from E.Merck,

\section{Instrumentation and analytical conditions}

The analysis of the drug was carried out on Shimadzu HPLC model (VP series) containing LC-20AT (VP series) pump, variable wave length programmable UV/visible detector SPD-20A and rheodyne injector (7725i) with $20 \mu$ fixed loop. Chromatographic analysis was performed using phenolex C-18 column with 250 x 4.6mm internal diameter and $5 \mu \mathrm{m}$ particle size. Shimadzu electronic balance (AX200) was used for weighing. Isocratic elution with, Acetonitrile, 0.1MAcetic Acid 50:50(v/v) was selected with a flow rate of $1.2 \mathrm{ml} / \mathrm{min}$.The detection wavelength was set at $210 \mathrm{~nm}$ with a run time of $10 \mathrm{~min}$. The mobile phase was prepared freshly and it was degassed by sonicating for $5 \mathrm{~min}$ before use. The column was equilibrated for at least $30 \mathrm{~min}$ with the mobile phase flowing through the system. The column and the HPLC system were kept at ambient temperature.

Preparation of Stock, working standard solutions and Sample solutions

$10 \mathrm{mg}$ of Paracetamol was weighted and transferred into a $10 \mathrm{ml}$ volumetric flask. Water was added and sonicated to dissolve it completely and made up to the mark with the same solvent. Further $10 \mathrm{ml}$ of the above stock solution was pipette into a $100 \mathrm{ml}$ volumetric flask and diluted up to the mark with water. The contents were mixed well and filtered through Ultipor N66Nylon 6, 6 membrane sample filter paper. The calibration curve was plotted with the concentrations of the 100 to $140 \mathrm{ppm}$ solutions. Calibration solutions were prepared and analyzed immediately after preparation. 


\section{International Journal of Science and Research (IJSR) \\ ISSN (Online): 2319-7064 \\ Index Copernicus Value (2013): 6.14 | Impact Factor (2014): 5.611}

Table 1 chromatographic condition for Paracetamol

\begin{tabular}{|c|c|c|}
\hline S.NO & Test & Result \\
\hline & H.P.L.C CONDITIONS & \\
\hline 2 & Elution & ISOCRATIC \\
\hline 3 & A.P.I Conc. & 100ppm \\
\hline 4 & Mobile Phase & $\begin{array}{c}\text { Acetonitrile:0.1M } \\
\text { Acetic Acid(50:50) }\end{array}$ \\
\hline 5 & $\mathrm{pH}$ & 3.0 \\
\hline 6 & Column & C18 \\
\hline 7 & Wavelength & $210 \mathrm{~nm}$ \\
\hline 8 & Rlow Rate & $1.2 \mathrm{ml} / \mathrm{min}$ \\
\hline 9 & Retention Time & $10 \mathrm{Min}$ \\
\hline 10 & Area & 2.850 \\
\hline 11 & Th.Plates & 1525.843 \\
\hline 12 & Tailing Factor & 9950 \\
\hline 13 & Pump Presure & 7.089 \\
\hline
\end{tabular}

\section{Method Validation procedure}

The objective of the method validation is to demonstrate that the method is suitable for its

Intended purpose as it is stated in ICH guidelines. The method was validated for linearity, precision, accuracy, specificity, and limit of detection, limit of quantification, robustness and system suitability.

\section{Linearity}

Table 2: Linearity of Paracetamol

\begin{tabular}{|c|c|c|}
\hline S. No & Conc & Area \\
\hline 1 & $100 \mathrm{ppm}$ & 1525.843 \\
\hline 2 & $110 \mathrm{ppm}$ & 1678.427 \\
\hline 3 & $120 \mathrm{ppm}$ & 1831.011 \\
\hline 4 & $130 \mathrm{ppm}$ & 1985.595 \\
\hline 5 & $140 \mathrm{ppm}$ & 2156.180 \\
\hline
\end{tabular}

The developed method has been validated as per ICH guidelines.Solutions of Paracetamol in the mass concentration range of $100 \mathrm{ppm}$ to $140 \mathrm{ppm}$ was injected into the chromatographic system. The chromatograms were developed and the peak area was determined for each concentration of the drug solution. Calibration curve of Paracetamol was obtained by plotting the peak area ratio versus the applied concentrations of Paracetamol. The linear correlation coefficient was found to be 0.9997

Table.3 Linear Regression Data for Calibration curve

\begin{tabular}{|c|c|}
\hline Drug & Paracetamol \\
\hline Concentration range & $100-140 p p m$ \\
\hline Slope (m) & 15.25 \\
\hline Intercept (b) & 0.843 \\
\hline Correlation coefficient & 0.9997 \\
\hline
\end{tabular}

\section{Precision}

Repeatability of the method was checked by injecting replicate injections of $100 \mathrm{ppm}$ of the solution for five times on the same day as intraday precision study of Paracetamol and the RSD was found to be 0.1238 for intraday and 0.1162 for interday
Table 4: Precision parameters of Paracetamol

\begin{tabular}{|c|c|c|c|}
\hline Injection & Concentration & Intra Day & Inter Day \\
\hline 1 & $100 \mathrm{ppm}$ & 1529.144 & 1679.315 \\
\hline 2 & $100 \mathrm{ppm}$ & 1526.182 & 1678.418 \\
\hline 3 & $100 \mathrm{ppm}$ & 1530.277 & 1678.678 \\
\hline 4 & $100 \mathrm{ppm}$ & 1525.917 & 1675.889 \\
\hline 5 & $100 \mathrm{ppm}$ & 1527.340 & 1674.834 \\
\hline & RSD & 0.1238 & 0.1162 \\
\hline
\end{tabular}

\section{Accuracy}

The accuracy of the method was determined by calculating recovery of Paracetamol by the method of standard addition. Known amount of Paracetamol (100 ppm) was added to a pre-quantified sample solution and the amount of Paracetamol was estimated by measuring the peak area ratios and by fitting these values to the straight line equation of calibration curve. The recovery studies were carried out three times over the specified concentration range and amount of Paracetamol was estimated by measuring the peak area ratios by fitting these values to the straight line equation of calibration curve.

\section{Specificity}

The specificity of the method was determined by comparing test results obtained from analysis of sample solution containing excipients with that of test results those obtained from standard drug.

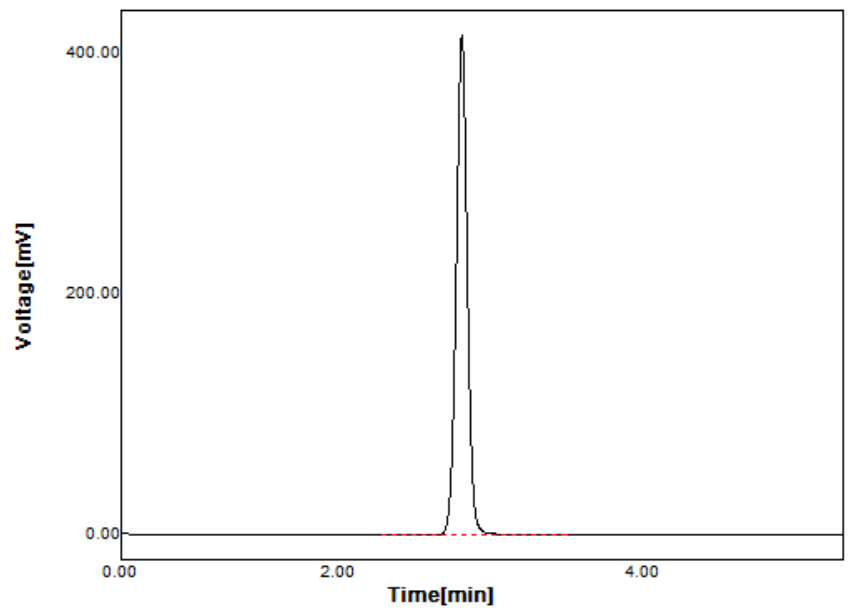

Figure: Typical chromatogram of Paracetamol

\section{LOD and LOQ}

Limit of detection (LOD) and limit of quantification (LOQ) were calculated as $1 \mathrm{ppm}$ and $10 \mathrm{ppm}$ respectively as per ICH guide-lines. Results are shown in table 5.

Table 5: Results of LOD and LOQ.

\begin{tabular}{|c|c|}
\hline Parameter & Measured \\
\hline LOD & $1 \mathrm{ppm}$ \\
\hline LOQ & $10 \mathrm{ppm}$ \\
\hline
\end{tabular}

\section{Robustness}

To determine the robustness of the method, two parameters from the optimized chromatographic conditions were varied. First, Instrument and place were changed and second $\mathrm{pH}$ was changed 3.0 to 2.8. Results of Robustness are shown in table $6 \& 7$. 


\section{International Journal of Science and Research (IJSR) \\ ISSN (Online): 2319-7064}

Index Copernicus Value (2013): 6.14 | Impact Factor (2014): 5.611

Table 6: Robustness parameters

\begin{tabular}{|c|c|}
\hline Parameter & Modification \\
\hline M.PHASE & $\begin{array}{r}\text { Acetonitrile:0.1M Acetic } \\
\text { Acid(50:50) }\end{array}$ \\
\hline PH & 2.8 \\
\hline WAVELENGTH & $210 \mathrm{~nm}$ \\
\hline R.T & $2.503 \mathrm{Min}$ \\
\hline
\end{tabular}

Table 7: Robustness results

\begin{tabular}{|c|c|}
\hline Accuracy & Precision \\
\hline 1606.903 & 1587.266 \\
\hline 1606.503 & 1586.729 \\
\hline 1606.511 & 1589.328 \\
\hline & 1584.277 \\
\hline & 1584.566 \\
\hline & \\
\hline RSD: 0.014 & RSD: 0.131 \\
\hline
\end{tabular}

\section{System Suitability Parameter}

System suitability tests were carried out on freshly prepared standard stock solutions of Paracetamol and it was calculated by determining the standard deviation of Paracetamol standards by injecting standards in five replicates at 5 minutes interval and the values were recorded in Table 8.

Table 8: System suitability parameters of Paracetamol

\begin{tabular}{|c|c|}
\hline Parameters & Values \\
\hline$\lambda$ max $(\mathrm{nm})$ & $210 \mathrm{~nm}$ \\
\hline $\begin{array}{c}\text { Correlation } \\
\text { coefficient }\end{array}$ & 0.9997 \\
\hline Retention time & $2.850 \mathrm{~min}$ \\
\hline Theoretical plates & 9950 \\
\hline Tailing factor & 1.089 \\
\hline Limit of detection & $1 \mathrm{ppm}$ \\
\hline $\begin{array}{c}\text { Limit of } \\
\text { quantification }\end{array}$ & $10 \mathrm{ppm}$ \\
\hline
\end{tabular}

\section{Result and Discussion}

\section{Optimization of the chromatographic conditions}

The nature of the sample, its molecular weight and solubility decides the proper selection of the stationary phase. The drug Paracetamol being non-polar is preferably analyzed by reverse phase columns and accordingly C18 column was selected. So the elution of the compound from the column was influenced by polar mobile phase. Different mobile phases were tried but satisfactory separation, well resolved and good symmetrical peaks were obtained with the mobile phase Acetonitrile: 0.1M Acetic Acid (50:50).The retention time of Paracetamol was found to be $2.850 \mathrm{~min}$, which indicates a good base line. The RSD values for accuracy and precision studies obtained were less than $2 \%$ which revealed that developed method was accurate and precise.

\section{Conclusion}

A validated RP-HPLC method has been developed for the determination of Paracetamol in bulk form. The proposed method is simple, rapid, accurate, precise and specific. Its chromatographic run time of 2.850 min allows the analysis of a large number of samples in short period of time.
Therefore, it is suitable for the routine analysis of Paracetamol in pharmaceutical analysis.

\section{References}

[1] www.wikipedia.com

[2] www.sciencedirect.com

[3] Aghababian, Richard V. (22 October 2010). Essentials of Emergency Medicine. Jones \& Bartlett Publishers. p. 814. ISBN 978-1-4496-1846-9.

[4] Ahmad, Jawad (17 October 2010). Hepatology and Transplant Hepatology: A Case Based Approach. Springer. p. 194. ISBN 978-1-4419-7085-5.

[5] Scottish Intercollegiate Guidelines Network (SIGN) (2008). "6.1 and 7.1.1". Guideline 106: Control of pain in adults with cancer (PDF). Scotland: National Health Service (NHS). ISBN 9781905813384.

[6] "www.fda.gov" (PDF).

[7] R Gopinath, S rajan et al. "A RP HPLC method for simultaneous estimation of paracetamol and aceeclofenac in tablets", www.ijpsonline.com, 2007: vol- 69, page : 137-140, 0250-474X

[8] B.Gowramma, S.Rajan and et al. „A validated RP HPLC method for simultaneous estimation of Paracetamol and Diclofenac Potassium in pharmaceutical formulation", International Journal of Chem Tech Research CODEN(USA): IJCRGG, ISSN: 0974 - 4290, VOL-2, No. 1,pp 676-680,Jan-Mar 2010. 